\title{
MENINGKATKAN KUALITAS PEMBELAJARAN \\ GURU KELAS IV, V, VI DALAM RANGKA MEWUJUDKAN \\ PEMBELAJARAN AKTIF, KREATIF, EFEKTIF, DAN MEYENANGKAN \\ (PAKEM) MELALUI SUPERVISI KELAS BERSAHABAT \\ DI SD NEGERI 4 SUMERTA SEMESTER II \\ TAHUN PELAJARAN 2017/2018
}

Dra. I.A Putri Masyanuida ${ }^{1}$

\begin{abstract}
ABSTRAK
Penelitian Tindakan Sekolah (PTS) ini dilatarbelakangi oleh dimana sebagian besar guru khususnya di kelas IV, V, VI SDN 4 Sumerta masih menggunakan cara-cara konvensional dalam mengajar, sehingga kualitas pembelajaran secara umum kurang maksimal. Tujuan penelitian ini adalah untuk menjelaskan peningkatan kualitas pembelajaran guru kelas IV, V, VI dalam rangka mewujudkan pembelajaran aktif, kreatif, efektif, dan meyenangkan (PAKEM) melalui supervisi kelas bersahabat.

Teknik pengumpulan data yang digunakan meliputi wawancara, observasi dan dokumentasi. Subyek penelitian tindakan sekolah ini ditentukan menggunakan tekhnik purposive sampling yaitu 3 (tiga) orang guru di SD Negeri 4 Sumerta yang berstatus PNS (guru kelas IV, guru kelas V, dan guru kelas VI).

Rancangan penelitian ini adalah model siklus yang dilakukan secara berulang dan berkelanjutan melalui dua siklus, yang setiap siklus berisi empat langkah yaitu: tahap perencanaan, tahap pelaksanaan, tahap observasi dan tahap refleksi. Hipotesis dianalisis menggunakan metode deskriptif pendekatan analisis kualitatif. Langkahlangkah analisis data yang digunakan meliputi pengumpulan data (data collection), reduksi data (data reduction), penyajian data (data display), dan penarikan kesimpulan atau verifikasi (conclutions).

Hasil penelitian tindakan sekolah menemukan nilai rata-rata kualitas pembelajaran Guru pada siklus II yakni 86,5 berada pada kategori "baik" (80 - 89). Terjadi peningkatan sebesar 7,7\% jika dibandingkan pada siklus I, rata-rata kualitas pembelajaran Guru adalah 78,8. Artinya bahwa Supervisi Kelas Bersahabat dapat meningkatkan kualitas pembelajaran Guru Kelas IV, V, VI dalam rangka mewujudkan PAKEM di Sekolah Dasar Negeri 4 Sumerta Semester II Tahun Pelajaran 2017/2018.
\end{abstract}

Kata kunci: Supervisi kelas bersahabat, kualitas pembelajaran guru, PAKEM

\section{PENDAHULUAN}

Pendidikan merupakan suatu pilar kehidupan bangsa. Proses pendidikan sangat menentukan kepribadian, skill serta budi pekerti individu. Masa depan suatu bangsa dapat diketahui melalui sejauh mana komitmen individu, masyarakat, 
bangsa atau negara dalam menyelenggarakan pendidikan nasional.

Ekosusilo (1993) mengungkapkan bahwa pendidikan merupakan salah satu aspek penting dalam kehidupan bangsa, sehingga pendidikan dapat dipandang sebagai salah satu bentuk investasi. Melalui pendidikan seseorang dibekali berbagai pengetahuan keterampilan, nilai dan sikap yang diperlukan untuk bekerja secara produktif.

Sekolah merupakan suatu lembaga pendidikan formal yang menyelenggarakan kegiatan proses belajar mengajar sebagai upaya untuk tercapainya tujuan pendidikan. Tinggi rendahnya mutu pendidikan banyak dipengaruhi oleh kualitas proses pembelajaran yang dilakukan oleh guru, karena guru secara langsung memberikan bimbingan dan bantuan kepada siswa dalam upaya mencapai tujuan pendidikan. Guru diharapkan mampu berperan aktif sebagai pengelola proses belajar mengajar, bertindak sebagai fasilitator yang selalu berusaha menciptakan organisasi kelas, penggunaan metode mengajar maupun sikap dan karakteristik guru dalam mengelola proses belajar mengajar (Wijaya, 1999: 2).

Pembelajaran Aktif, Kreatif, Efektif, dan Meyenangkan (PAKEM) merupakan proses pembelajaran dimana guru harus menciptakan suasana sedemikian rupa sehingga siswa aktif bertanya, mempertanyakan, dan mengemukakan gagasan. Upaya meningkatkan kualitas layanan dalam kualifikasi profesionalisme guru dalam rangka mewujudkan Pembelajaran Aktif, Kreatif, Efektif, dan Meyenangkan (PAKEM) tidak terlepas dari bantuan dan bimbingan dari supervisor. Dalam melaksanakan tugasnya, seorang supervisor berkewajiban membantu guru memberi dukungan yang dapat melaksanakan tugas dengan baik sebagai pendidik maupun pengajar.

Permasalahan yang terjadi di SDN 4 Sumerta, kualitas pembelajaran di kelas IV, V, dan VI secara umum masih kurang maksimal. Hal ini dikarenakan proses belajar mengajar di kelas tersebut sebagian besar guru masih menggunakan cara-cara konvensional. Alasan lain yang menjadi dasar pemikiran dalam penelitian ini, Peneliti yang sekaligus adalah Kepala Sekolah SDN 4 Sumerta menyadari tanggung jawab atas kualitas pembelajaran yang dilakukan oleh guru, untuk 
melakukan kegiatan supervisi yang terprogram yaitu supervisi kelas bersahabat. Teknik-teknik kegiatan ini diadopsi dari program BPS-DBE2 yang bertujuan meningkatkan mutu pembelajaran di sekolah dasar di Indonesia melalui pendekatan yang inovatif dalam rangka memperkuat sistem pelatihan guru dan meningkatkan lingkungan belajar.

Supervisi kelas bersahabat dapat dilakukan dengan membuat kesepakatan membagi peran antara supervisor dan guru dengan memposisikan diri dalam dua peran yakni sebagai tim pengajar dan sebagai pengamat. Penulis meyakini, melalui supervisi bersahabat pada guru kelas IV, V, dan VI akan meningkatkan kualitas pembelajaran dalam rangka mewujudkan Pembelajaran Aktif, Kreatif, Efektif, dan Meyenangkan (PAKEM). Hal inilah yang mendorong dan memotivasi penulis untuk melakukan penelitian tindakan sekolah dengan memilih topik yaitu: "Meningkatkan Kualitas Pembelajaran Guru Kelas IV, V, VI dalam rangka mewujudkan Pembelajaran Aktif, Kreatif, Efektif, dan Meyenangkan (PAKEM) Melalui Supervisi Kelas Bersahabat di Sekolah Dasar Negeri 4 Sumerta Semester II Tahun Pelajaran 2017/2018”.

\section{KAJIAN PUSTAKA}

\section{Pengertian Kualitas Pembelajaran}

Kualitas dapat dimaknai dengan istilah mutu atau juga keefektifan. Menurut Etzioni (dalam Hamdani, 2011:194) secara definitif efektivitas dapat dinyatakan sebagai tingkat keberhasilan dalam mencapai tujuan atau sasarannya. Kualitas adalah ukuran baik buruknya sesuatu, kadar, mutu, derajad/taraf (kepandaian/ kecakapan, dan sebagainya). Pembelajaran merupakan terjemahan dari Learning. Pembelajaran dapat diartikan sebagai upaya guru membantu siswa melakukan kegiatan belajar untuk mengubah tingkah laku siswa kearah yang lebih baik. ualitas pembelajaran secara operasional dapat diartikan sebagai intensitas keterkaitan sistemik dan sinergis guru dengan siswa, iklim pembelajaran, materi, media, fasilitas, dan sistem pembelajaran dalam menghasilkan proses dan hasil belajar yang optimal sesuai dengan tuntutan kurikulum. (Depdiknas, 2004: 7).

\section{Hakikat Pembelajaran Aktif, Kreatif, Efektif, dan Meyenangkan (PAKEM)}

PAKEM adalah singkatan dari Pembelajaran Aktif, Kreatif, Efektif, dan 
Menyenangkan. Menurut Suparlan (2008: 70-71), karakterisitk PAKEM, meliputi:

1) Aktif: pembelajaran ini memungkinkan peserta didik berinteraksi secara aktif dengan lingkungan, memanipulasi obyek-obyek yang ada di dalamnya, dalam hal ini guru terlibat secara aktif, baik dalam merancang, melaksanakan, dan mengevaluasi proses pembelajaran

2) Kreatif: Pembelajaran membangun kreativitas peserta didik dalam berinteraksi dengan lingkungan, bahan ajar dan sesama peserta didik, utamanya dalam menghadapi tantangan atau tugas-tugas yang harus diselesaikan dalam pembelajaran. Guru dituntut untuk kreatif, yaitu merancang dan melaksanakan PAKEM

3) Efektif: Efektifitas pembelajaran akan mendongkrak kualitas hasil bekajar peseta didik

4) Menyenangkan: Pembelajaran diharapkan dapat menciptakan suasana pembelajaran yang menyenangkan, dengan didukung lingkungan aman, bahan ajar relevan, menjamin bahwa belajar secara emosional adalah positif, yang pada umunya hal itu terjadi ketika dilakukan bersama dengan orang lain sebagai dorongan dan selingan humor serta istirahat dan jeda secara teratur. Selain itu, pembelajaran akan menyenangkan manakala secara sadar pikiran otak kiri dan kanan sadar, menantang peserta didik berekspresi dan berfikir jauh ke depan, serta mengonsolidasikan bahan yang sudah dipelajari dengan meninjau ulang dalam periode-periode yang santai.

\section{Kepala Sekolah}

Wahjosumidjo (2005: 83) mendefinisikan Kepala Sekolah sebagai seorang tenaga fungsional guru yang diberi tugas untuk memimpin suatu sekolah dimana diselenggarakan proses belajar mengajar, atau tempat dimana terjadi interaksi antara guru yang memberi pelajaran dan murid sebagai penerima pelajaran. Agar sekolah dapat mencapai tujuannya secara efektif dan efisien, maka kepala sekolah harus melaksanakan fungsi-fungsi manajerial seperti perencanaan, pengorganisasian, pengarahan, pemberian motivasi, pelaksanaan, pengorganisasian pengendalian, evaluasi dan inovasi.

\section{Hakikat Supervisi dan Supervisi Kelas Bersahabat}


Adam dan Dickey (1953) merumuskan supervisi sebagai pelayanan khususnya menyangkut perbaikan proses belajar mengajar. Supervisi dilakukan untuk melihat bagian mana dari kegiatan sekolah yg masih negatif untuk diupayakan menjadi positif, \& melihat mana yang sudah positif untuk ditingkatkan menjadi lebih positif lagi dan yang terpenting adalah pembinaannya.

DBE2 melakukan sebuah terobosan baru memecah kebekuan yang terjadi dalam supervisi kunjungan kelas selama ini. DBE2 bertujuan meningkatkan mutu pembelajaran di sekolah dasar di Indonesia melalui pendekatan yang inovatif dalam rangka memperkuat sistem pelatihan guru dan meningkatkan lingkungan belajar. Adapun program yang dibentuk berlebel BPS (Bantuan Profesional Sekolah) yang memberikan berbagai teknik baru dalam melakukan supervisi kunjungan kelas. Teknik-teknik yang dilaksanakan dalam BPS dapat diadopsi, sehingga supervisi kelas menjadi lebih "bersahabat".

Supervisi kelas yang bersahabat dapat dilakukan dengan membuat kesepakatan membagi peran antara supervisor dan guru dengan memposisikan diri dalam dua peran yakni sebagai tim pengajar dan sebagai pengamat. Dengan demikian kegiatan supervisi kelas yang bersahabat dikemudian hari dapat lebih diterima oleh guru sebagai hal yang sangatlah wajar atau bahkan merupakan hal yang dinanti-nantikan para guru (Osnal, 2016).

\section{Kerangka Berpikir}

Kerangka berpikir merupakan hasil abstraksi dari kerangka teori yang dikaitkan dengan masalah penelitian yang dihadapi. Seorang supervisor berkewajiban membantu guru memberi dukungan yang dapat melaksanakan tugas dengan baik sebagai pendidik maupun pengajar dalam rangka mewujudkan Pembelajaran Aktif, Kreatif, Efektif, dan Meyenangkan (PAKEM). Permasalahan yang terjadi dimana sebagian besar guru khususnya di kelas IV, V, VI SDN 4 Sumerta masih menggunakan cara-cara konvensional dalam mengajar, sehingga kualitas pembelajaran secara umum kurang maksimal. Alasan lain yang menjadi dasar pemikiran dalam penelitian ini, Peneliti yang sekaligus adalah Kepala Sekolah SDN 4 Sumerta menyadari tanggung jawab atas kualitas pembelajaran yang dilakukan oleh guru, untuk melakukan kegiatan supervisi yang terprogram 
yaitu melakukan supervisi kelas bersahabat. Supervisi dengan teknik ini tentunya tidak menakutkan bagi guru, tetapi justru merupakan hal yang dinanti-nanti oleh para guru.

Hal ini lah yang mendorong dan memotivasi peneliti untuk melakukan Penelitian Tindakan Sekolah (PTS) dengan proses atau siklus berulang, bertahap, dan berkelanjutan yang pelaksanaannya direncanakan melalui dua siklus. Setiap siklus meliputi empat tahapan yakni tahap perencanaan, tahap pelaksanaan, tahap observasi dan tahap refleksi. Data dalam penelitian ini dianalisis menggunakan metode deskriptif dengan pendekatan analisis kualitatif. Langkah-langkah analisis data yang digunakan meliputi pengumpulan data (data collection), reduksi data (data reduction), penyajian data (data display), dan penarikan kesimpulan atau verifikasi (conclutions).

\section{Hipotesis Penelitian}

Berdasarkan kajian teori dan kerangka berpikir di atas maka diajukan hipotesis, yaitu: Supervisi Kelas Bersahabat dapat meningkatkan kualitas pembelajaran Guru Kelas IV, V, VI dalam rangka mewujudkan PAKEM di Sekolah Dasar Negeri 4 Sumerta Semester II Tahun Pelajaran 2017/2018.

\section{METODOLOGI PENELITIAN}

Lokasi penelitian ini adalah di Sekolah Dasar Negeri 4 Sumerta yang beralamat di Jalan Hayam Wuruk No. 132 Denpasar Timur. Penelitian ini dilaksanakan pada semester semester II yaitu mulai tanggal 22 Januari sampai dengan tanggal 21 Mei 2018. Dalam penelitian ini posisi peneliti sebagai kepala sekolah di SD Negeri 4 Sumerta Tahun Pelajaran 2017/2018.

Subyek penelitian ini adalah 3 (tiga) orang guru di SD Negeri 4 Sumerta yang berstatus PNS yakni guru kelas IV, guru kelas V, dan guru kelas VI. Pemilihan subjek penelitian melalui tekhnik purposive sampling yaitu tekhnik pengambilan sampel sumber data dengan pertimbangan tertentu, diantaranya dianggap paling tahu tentang apa yang diharapkan, atau sebagai penguasa sehingga memudahkan peneliti menjelajahi obyek atau situasi social yang diteliti (Sugiyono, 2016:219).

Teknik pengumpulan data yang digunakan meliputi wawancara, observasi dan dokumentasi. Penelitian ini merupakan Penelitian Tindakan Sekolah/PTS 
(School Action Research). Rancangan penelitian yang dipilih yaitu model siklus yang direncanakan melalui dua siklus. Setiap siklus berisi empat langkah yaitu: tahap perencanaan, tahap pelaksanaan, tahap observasi dan tahap refleksi. Hipotesis dibuktikan dengan cara melakukan analisis menggunakan metode deskriptif pendekatan analisis kualitatif. Langkah-langkah analisis data yang digunakan meliputi pengumpulan data (data collection), reduksi data (data reduction), penyajian data (data display), dan penarikan kesimpulan atau verifikasi (conclutions).

Tolok ukur keberhasilan penelitian ini adalah: kualitas pembelajaran guru kelas IV, V, VI dalam rangka mewujudkan Pembelajaran Aktif, Kreatif, Efektif, dan Meyenangkan (PAKEM) meningkat dengan skor nilai rata-rata $\geq 80$ yang berada pada ketegori "Baik".

Kualitas pembelajaran guru kelas IV, V, dan VI dalam rangka mewujudkan pembelajaran aktif, kreatif, efektif, dan meyenangkan (PAKEM) melalui supervisi kelas bersahabat di Sekolah Dasar Negeri 4 Sumerta Semester II Tahun Pelajaran 2017/2018 akan diukur menggunakan enam indikator, yakni sebagai berikut: (1) perilaku pembelajaran guru, (2) perilaku dan dampak belajar siswa, (3) iklim pembelajaran, (4) materi pembelajaran, (5) media pembelajaran yang berkualitas, dan (6) sistem pembelajaran disekolah untuk mencapai tujuan pembelajaran.

Indikator-indikator tersebut diukur menggunakan skala likert dengan empat kategori penilaian (1=kurang; 2=cukup; 3=baik; 4=baik sekali). Adapun formulasi penghitungan nilai menurut Suharsimi Arikunto (2010:90) adalah sebagai berikut:

Skor $=\frac{\text { Jumlah nilai riil }}{\text { Jumlah nilai ideal }} \times 100 \%$

\section{HASIL PENELITIAN DAN PEMBAHASAN}

Penelitian tindakan ini dikatakan berhasil apabila kualitas pembelajaran guru kelas IV, V, dan VI dalam rangka mewujudkan Pembelajaran Aktif, Kreatif, Efektif, dan Meyenangkan (PAKEM) meningkat dengan skor nilai rata-rata $\geq 80$ yang berada pada ketegori "Baik".

Secara keseluruhan proses penelitian telah dilakukan bertahap melalui dua 
siklus. Perkembangan yang dicapai telah menunjukkan hasil yang baik. Dalam konteks program pembelajaran, tanpa mengurangi arti penting serta tanpa mengesampingkan faktor-faktor lainnya yang tidak diteliti, faktor kualitas pembelajaran merupakan faktor yang sangat berperan dalam meningkatkan hasil pembelajaran yang pada akhirnya berujung pada meningkatnya kualitas pendidikan.

Berdasarkan tabel dan grafik di bawah ini, dapat diketahui hasil penelitian mulai dari siklus I sampai dengan siklus II. Perhatikan Tabel 4.3 di bawah ini.

Tabel 4.3

Rekap hasil penelitian Siklus I sampai dengan Siklus II

\begin{tabular}{rcccc}
\hline & Siklus I & Siklus II & $\begin{array}{c}\text { Selisih } \\
\text { (Naik/Turun) }\end{array}$ & Ket. \\
\hline Ni Md Ninik Erlya Dewi & 76,0 & 83,7 & 7,7 & Naik \\
I Kadek Dana & 81,7 & 90,4 & 8,7 & Naik \\
Ni Nyoman Budhi S & 78,8 & 85,6 & 6,7 & Naik \\
\hline Rata-rata & $\mathbf{7 8 , 8}$ & $\mathbf{8 6 , 5}$ & &
\end{tabular}

Tabel 4.3 menunjukkan nilai rata-rata pada siklus I yakni 78,8 berada pada kategori "cukup" (60 - 79). Hal ini bermakna penelitian tindakan sekolah pada siklus I cukup baik namun belum mencapai target penelitian dan diputuskan untuk memperbaiki beberapa langkah pada siklus II. Nilai rata-rata pada siklus II yakni 86,5 berada pada kategori "baik" (80 - 89). Dengan demikian, peningkatan yang mampu dicapai selama dua siklus adalah $7,7 \%$.

Untuk memperjelas hasil penelitian tindakan ini, perhatikan grafik 4.1, yaitu Grafik Peningkatan kualitas pembelajaran Guru Kelas IV, V, VI dalam rangka mewujudkan PAKEM melalui Supervisi Kelas Bersahabat dari Siklus I sampai dengan Siklus II. 


\section{Chart Title}

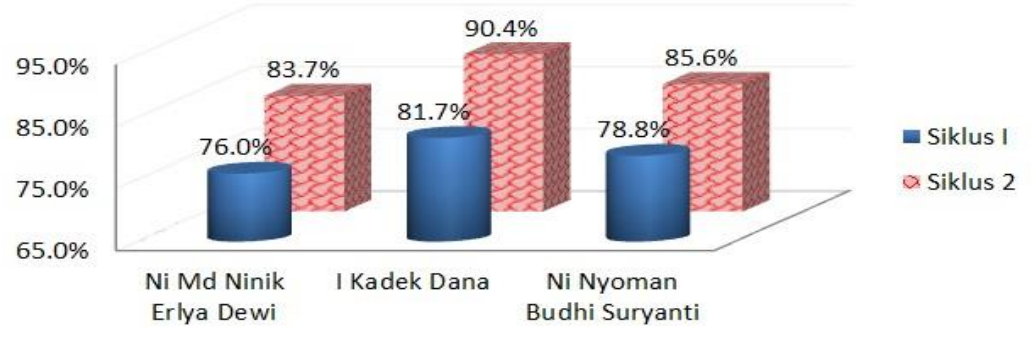

Grafik 4.1

\section{Peningkatan kualitas pembelajaran Guru Kelas IV, V, VI dalam rangka mewujudkan PAKEM melalui Supervisi Kelas Bersahabat dari Siklus I s.d Siklus II}

Berdasarkan grafik 4.1 di atas, dapat dilihat kualitas pembelajaran guru kelas IV, V, dan VI selama penelitian tindakan mulai dari siklus I sampai dengan siklus II. Terdapat peningkatan yang signifikan.

Dengan demikian Hipotesis yang diajukan pada penelitian tindakan ini dapat diterima yakni Supervisi Kelas Bersahabat dapat meningkatkan kualitas pembelajaran Guru Kelas IV, V, VI dalam rangka mewujudkan PAKEM di Sekolah Dasar Negeri 4 Sumerta Semester II Tahun Pelajaran 2017/2018.

Guru diharapkan mampu menciptakan Pembelajaran Aktif, Kreatif, Efektif, dan Meyenangkan (PAKEM), dengan demikian kegiatan supervisi kelas yang bersahabat dikemudian hari dapat diterima oleh guru sebagai hal yang sangatlah wajar atau bahkan merupakan hal yang dinanti-nantikan para guru (Osnal, 2016). Kepala Sekolah juga wajib untuk menciptakan kondisi yang memungkinkan bagi lahirnya iklim kerja dan hubungan antar manusia yang harmonis dan kondusif. Hal ini berarti seluruh komponen pendidikan di sekolah harus dikembangkan secara terpadu dalam rangka meningkatkan relevansi atau kesesuaian untuk menjamin kualitas pendidikan.

\section{SIMPULAN DAN SARAN}

Berdasarkan pembahasan hasil penelitian, maka dapat ditarik simpulan yakni Supervisi Kelas Bersahabat dapat meningkatkan kualitas pembelajaran Guru Kelas IV, V, VI dalam rangka mewujudkan PAKEM di Sekolah Dasar Negeri 4 
Sumerta Semester II Tahun Pelajaran 2017/2018. Hal ini dibuktikan dengan melihat nilai rata-rata kualitas pembelajaran Guru pada siklus II yakni 86,5 berada pada kategori "baik" $(80-89)$. Terjadi peningkatan sebesar 7,7\% jika dibandingkan pada siklus I, rata-rata kualitas pembelajaran guru adalah 78,8.

Sehubungan dengan simpulan diatas, maka dapat dikemukakan beberapa saran sebagai berikut:

4) Kepala sekolah diharapkan terus meningkatkan efektifitas pelaksanaan Supervisi Kelas Bersahabat agar kualitas pembelajaran Guru tercapai secara optimal.

5) Diperlukan usaha yang sungguh-sungguh untuk meningkatkan kualitas pembelajaran Guru dan mewujudkan pembelajaran aktif, kreatif, menyenangkan (PAKEM) baik yang berasal dari guru itu sendiri, kepala sekolah maupun instansi pemerintah yang terkait.

6) Hasil penelitian ini dapat dijadikan sebagai acuan untuk penelitian berikutnya, dan diharapkan mampu menggali lebih dalam mengenai gambaran yang luas dan mendalam tentang peningkatan kualitas pembelajaran Guru dalam rangka mewujudkan PAKEM agar diperoleh hasil yang lebih baik.

\section{DAFTAR PUSTAKA}

Arikunto, Suharsimi. 2010. Prosedur Penelitian: Suatu Pendekatan Praktik (Edisi Revisi). Rineka Cipta. Jakarta.

Carter V. Good, (ed).1973. Dictionary of Education, Third Edition. New York: McGraw-Hill.

Departemen Pendidikan Nasional. 2004. Kurikulum 2004. Jakarta: Depdiknas

Ekosusilo, Madyo. 1993. Dasar-dasar pendidikan. Semarang: Effhar Offset

Osnal. 2016. Meningkatkan Kualitas Pembelajaran Guru Kelas 6 Melalui Supervisi Kelas Bersahabat Di Gugus I Kecamatan Sumbermalang Kabupaten Situbondo Tahun Pelajaran 2015/2016. Jurnal Pancaran, Vol. 5, No. 1, hal 133-146, Pebruari 2016

Purwanto, Ngalim. 2010. Administrasi dan Supervisi Pendidikan. Bandung: PT Remaja Posdakarya.

Suparlan, dkk. 2008. PAKEM: Pembelajaran, Aktif, Kreatif, Efektif, Menyenangkan. Bandung: PT. Genesindo

Undang-Undang RI No 14 Tahun 2005, Guru dan Dosen, Bandung: Cita Umabara, 2006 
Usman, Moh. Uzer. 1994. Menjadi Guru Profesional. Bandung: PT. Remaja Rosdakarya.

Wahjosumidjo. 2005. Kepemimpinan Kepala Sekolah, Tinjauan Teori dan Permasalahannya. Jakarta: Raja Grafindo Persada 